\title{
Regeneration dynamics in fragmented landscapes at the leading edge of distribution: Quercus suber woodlands as a study case
}

\author{
Jorge Luis Montero-Muñoz (D) Carmen Ureña • Diego Navarro • Valentín Herrera • Pilar Alonso-Rojo (D) \\ Héctor Hernández-Alonso (D) María Fernanda Cepeda-González (D) Luis Carlos Jovellar • \\ Belén Fernández-Santos (i) Fernando Silla (1)
}

Received: 1 March 2021 / Accepted: 1 July 2021 / Published online: 5 August 2021

(C) The Author(s) 2021

\begin{abstract}
Aims We studied the regeneration dynamics of woodlands and abandoned old fields in a landscape dominated by Quercus suber in its lower limits of rainfall and temperature. Two hypotheses were established: (1) regeneration of Quercus species is strongly favored by the presence of tree cover; and (2) growth of $Q$. suber is driven by the climatic variables that represent the lower ecological limit of its leading distribution edge.

Methods We selected woodlands and old fields with and without tree remnants ( $n=3$ per type), and
\end{abstract}

Responsible Editor: Jeffrey Walck .

Supplementary Information The online version contains supplementary material available at https://doi. org/10.1007/s11104-021-05077-7.

J. L. Montero-Muñoz

Centro de Investigación y de Estudios Avanzados del Instituto Politécnico Nacional (CINVESTAV), Unidad de

Mérida, Mérida, Mexico

J. L. Montero-Muñoz $\cdot$ C. Ureña $\cdot$ D. Navarro $\cdot$ V. Herrera ·

H. Hernández-Alonso · M. F. Cepeda-González ·

B. Fernández-Santos · F. Silla $(\bowtie)$

Area of Ecology, Faculty of Biology, University

of Salamanca, Salamanca, Spain

e-mail: fsilla@usal.es

P. Alonso-Rojo

Area of Edaphology, Faculty of Agricultural

Environmental Sciences, University of Salamanca,

Salamanca, Spain analyzed stand structure, soil parameters and tree growth.

Results Succession was arrested in old fields without tree remnants. By contrast, remnant trees were accelerators of forest recovery in old fields. Tree cover played a fundamental role in Quercus recruitment throughout seed dispersal and facilitation that mitigate the effects of summer drought on seedlings. Also, tree cover improved soil parameters (e.g., organic matter) that are important factors for understanding differences in regeneration. Winter/spring precipitation exerted a positive effect on tree growth, as well as temperatures during winter/spring and September.

Conclusions Regeneration dynamics are modeled by the density of tree cover in the cold and dry edge of the distribution area of $Q$. suber where $Q$. ilex is

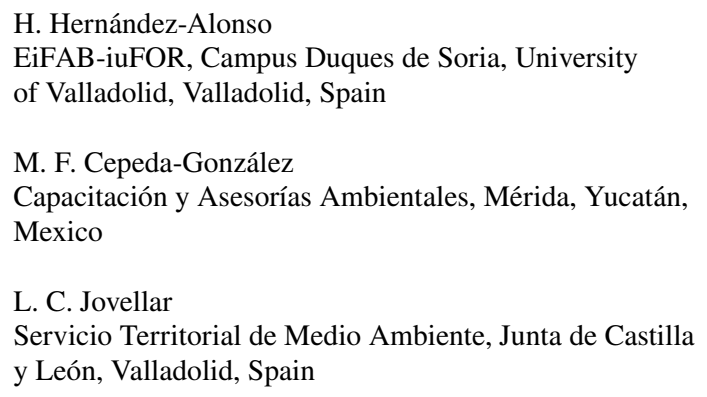


increasing in abundance. Although temperature has a positive effect on the tree growth of $Q$. suber, when demographic processes are considered, decreases in water availability likely play a critical role in $Q$. ilex recruitment. This in turn changes dominance hierarchies, especially in abandoned areas with little or no tree cover.

Keywords Quercus suber - Recruitment dynamics · Edge distribution · Secondary succession · Growthclimate relationships

\section{Introduction}

Human activity has influenced the structure and dynamics of forests in the Mediterranean region over centuries (Barbero et al. 1990; ScarasciaMugnozza et al. 2000; Chauchard et al. 2007; Camisón et al. 2015). This is the case of forests and woodlands dominated by the cork oak, $Q$. suber L., which managed systems that are protected by the European Union (Habitat directive 92/43/EEC). $Q$. suber is an evergreen tree species present in the western Mediterranean region that extends through the Iberian Peninsula to the western rim of the Italian peninsula, as well as some Mediterranean islands (Corsica, Sardinia, Sicilia and Balearic Islands) and coastal plains and hilly areas in North Africa, ranging from Morocco to Tunisia (Blanco et al. 1997; Magri et al. 2007; Pausas et al. 2009a). Covering about 2.2 million hectares, the current distribution area of this species is rather patchy, suggesting that in the past there was a more continuous distribution and that much of what we see today is relictual (Blanco et al. 1997; Carrión et al. 2000; Sánchez-Palomares et al. 2007; Pausas et al. 2009a; Jovellar et al. 2010). Additionally, intensification of ongoing climate change is expected to increase temperatures and the length of dry spells in the Mediterranean basin (Kovats et al. 2014). Consequently, areas suitable for cork oak are predicted to become generally reduced over the twenty-first century, owing also to intermediate and high $\mathrm{CO}_{2}$ emission scenarios (Pereira et al. 2009; Vessella et al. 2017).

Cork oak can form closed woodlands, but in most parts of its geographic distribution in the Iberian Peninsula and North Africa it usually appears in open woodlands with other dominating or co-dominating Quercus (Q.ilex, Q.faginea) or Pinus (P. pinea, P.pinaster) species (Blanco et al. 1997; Bugalho et al. 2009). Moreover, these open woodlands have been traditionally managed as agro-silvopastoral systems providing mainly cork, but also goods such as pasture for livestock, acorns for the high-quality pork industry, cereal crops, firewood and game species. Also, these woodlands provide services in the form of recreational tourism, as cork oak systems represent an important cultural heritage in the Mediterranean region (Bugalho et al. 2009; Ovando et al. 2009; Vallejo et al. 2009). However, in many parts of Europe, since the second half of the twentieth century, the Iberian Peninsula has been subjected to substantial land abandonment due to socioeconomic factors. These factors have led to the decline and/or disappearance of traditional management systems, crop abandonment, shrub encroachment and an increased risk of fire (Bugalho et al. 2009; Vallejo et al. 2009). The recruitment of oaks after land abandonment is usually a slow process, especially in some shrublands (e.g. Cistus-dominated shrublands), where succession is strongly delayed or almost halted in a condition known as arrested succession (Pons and Pausas 2006; Acácio et al. 2007; Pausas et al. 2009a, b; Acácio and Holmgren 2014). Regeneration of $Q$. suber from seed shares problems and limitations that are similar to those experienced by other Quercus species in Mediterranean woodlands. Limitations to oak recruitment in Mediterranean environments may include: (a) High rates of acorn predation by invertebrates and vertebrates (Branco et al. 2002; Pons and Pausas 2006; Pausas et al. 2009b). (b) Limited dispersion by scatterhoarding rodents (Pons and Pausas 2007a), since the main long-distance vector the Eurasian jay, Garrulus glandarius (Pons and Pausas 2007b), is a forest species that is very scarce or absent in open woodlands (Pons and Pausas 2006). (c) High seedling mortality due to water stress during the summer in open areas (Pulido and Díaz 2005; Silla and Escudero 2004, Smit et al. 2009, PérezRamos et al. 2012). And (d), reduced seedling growth and high mortality by herbivore defoliation and trampling (Gómez et al. 2003; Silla and Escudero 2006; Rossetti and Bagella 2014; Costa et al. 2017). Due to these extreme limitations, tree cover is considered to play a fundamental role in 
Quercus recruitment both providing seeds for autoand zoochorus dispersal (Pulido and Díaz 2005; Acácio et al. 2007; Pausas et al. 2009b) and through facilitation effects (Caldeira et al. 2014; Ibáñez et al. 2015; Costa et al. 2017). Facilitation includes several direct and indirect mechanisms with positive effects on both survival and Quercus seedling growth. Among direct mechanisms, tree shading improves microclimate conditions reducing high summer temperatures and alleviating heat stress (Pulido and Díaz 2005; Pausas et al. 2009a, b, Smit et al. 2009), whereas litterfall production improves soil nutrient availability and water retention (Rawls et al. 2003; Serrasolses et al. 2009). On the other hand, tree cover indirectly reduces competition between Quercus seedlings and herbaceous vegetation (Caldeira et al. 2014).

In this work, we took advantage of the heterogeneity in tree cover (from abandon cultivated areas to woodlands) generated by anthropogenic activities as a representative case to study the regeneration dynamics at the leading distribution edge of $Q$. suber. This area is located in the lower ecological limits of rainfall and temperature supported by $Q$. suber, and forest dynamics and growth are expected to be highly influenced by climate warming. As such, we have established two main hypotheses. This first hypothesis states that the abundance of regeneration of Quercus species is strongly favored by the presence of trees in an increasing gradient of tree cover from abandoned cultivars to woodlands due to improving microclimate conditions and soil characteristics. In particular, we expect that in its lower ecological limits, $Q$. suber will be more restricted by the abiotic variations induced by the tree cover than other species more adapted to extreme Mediterranean conditions (i.e., $Q$. ilex). Therefore, abundance of $Q$. suber regeneration would respond more drastically to changes in tree cover throughout the landscape, and the spatial distribution of seedlings would be more associated with the presence of trees than in the case of $Q$. ilex. To address this hypothesis, stand structure, soil parameters and spatial patterns of trees, saplings and seedlings were analyzed in three types of landscape covers (abandoned cultivars without and with tree remnants and woodlands). The second hypothesis states that growth of $Q$. suber is driven by the climatic variables that are in the lower ecological limit of its leading distribution edge (precipitation and temperature). We expect that, in a context of global change, both warmer and dryer conditions have opposite effects on the tree growth of $Q$. suber in the North-Mediterranean region. Thus, warmer temperatures are expected to have a positive effect, extending the favorable growth period especially during the colder months. On the other hand, rainfall would also have a positive effect on tree growth, but a decrease in precipitation is predicted because of climate change. To address this hypothesis, a dendrochronological approach was used to study the influence of climate variable on ring-tree growth, and temporal trends of limiting climatic variables were analyzed.

\section{Material and methods}

Study site

The study area is located in the north subdivision of the Central plateau of the Iberian Peninsula in Salamanca province, Spain (Fig. 1a; $41^{\circ} 07^{\prime} \mathrm{N}, 5^{\circ}$ $47^{\prime} \mathrm{W}$; 800-850 $\mathrm{m}$ a.s.1.). The mean annual precipitation is around $380 \mathrm{~mm}$, with a typical Mediterranean period of low precipitation during July and August. The mean annual temperature is around $12{ }^{\circ} \mathrm{C}$, with mean temperatures between 3 and $4{ }^{\circ} \mathrm{C}$ and $20-21^{\circ} \mathrm{C}$ during the coldest and the warmest months, respectively. The study area covers around 4500 ha and contains the biggest $Q$. suber woodland in the northwest part of the Iberian Peninsula, with an extension of almost 2000 ha (Guerra Velasco 2015). The study area is located in the distributional edge of this species, as $Q$. suber typically occurs between 0 and $800 \mathrm{~m}$ a.s.l., it requires an annual precipitation between 600 and $1000 \mathrm{~mm}$ and an average temperature around $15{ }^{\circ} \mathrm{C}$ (Blanco et al. 1997; Sánchez-Palomares et al. 2007; Houston Durrant et al. 2016).

The study area is characterized by a variety of land covers, including open and closed woodlands (dominated by $Q$. suber and the presence of Quercus ilex subsp. ballota, Q.faginea and Q. pyrenaica), Pinus pinaster plantations, shrublands dominated by Cistus, Halimium and Cytisus species and abandoned cultivars. 

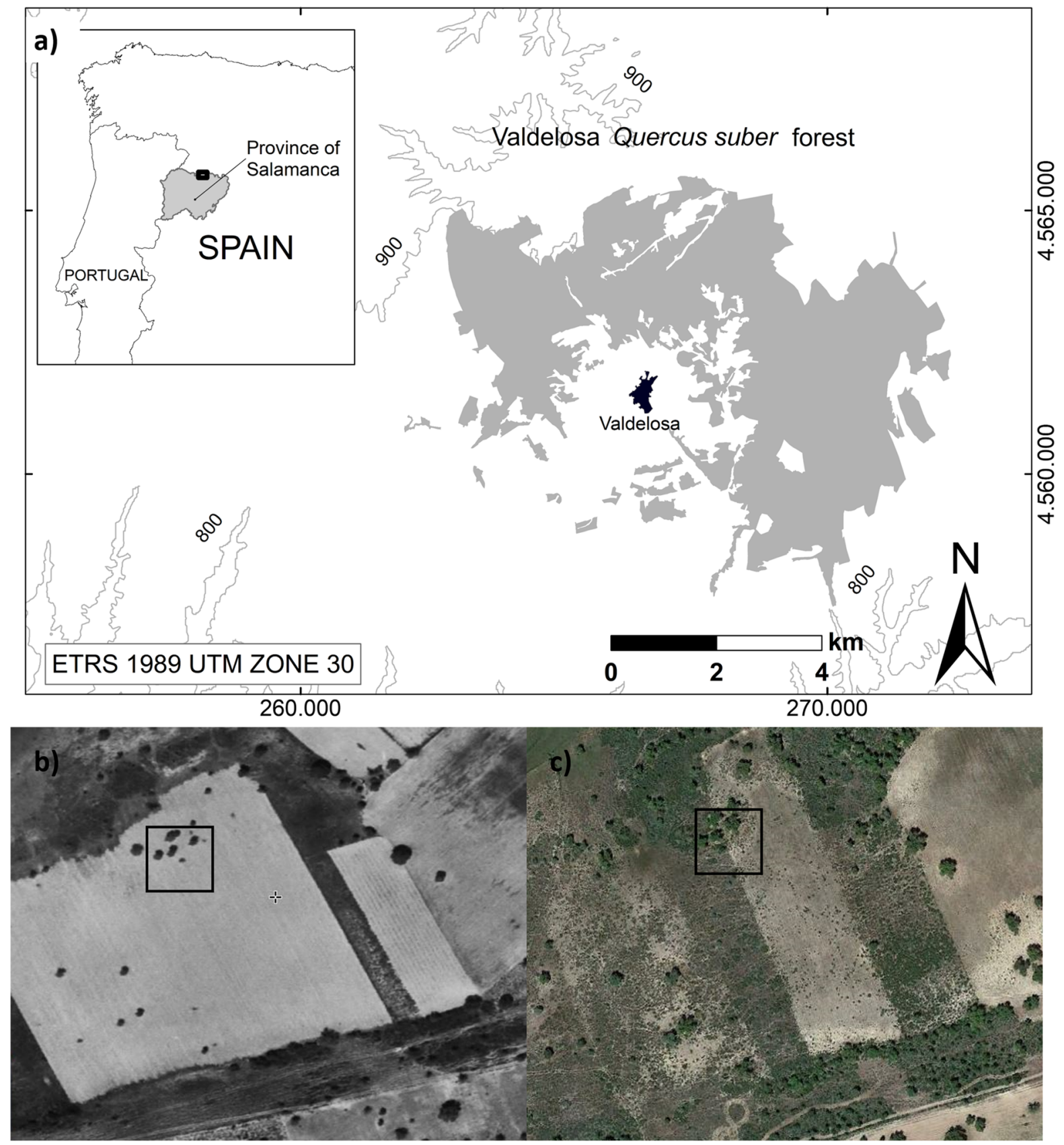

Fig. 1 (a) Location of the Quercus suber forest (grey area). Valdelosa municipality (black area) is shown. The black square indicates the position of the same plot (an old field with tree

Plot establishment and data collection on stand structure

Nine sites were selected encompassing three forest stands dominated by $Q$. suber, three old fields with remnants plot) in aerial photographs of the Spanish Inter-ministry flight from 1973 to 1986 (b) and aerial photographs taken from Google Earth (ㄷ 2015 Google) from 2015 (c)

tree remnants and three old fields without tree cover. Site selection was based on changes in landscape use determined by comparing aerial photographs of the Spanish Inter-ministry flight from 1973 to 1986 (https://fototeca.cnig.es) and aerial photographs taken 
from Google Earth from 2015 (Fig. 1b, c). The sites located in old fields, with and without tree remnants, had been cultivated in the 70s and 80s and abandoned in the late 1990s. The forest stands were noncultivated areas managed for traditional cork extraction, which is still harvested today. In each site, we established a $40 \times 40 \mathrm{~m}$ plot $\left(1600 \mathrm{~m}^{2}\right)$ where the origin point of each one was randomized and their sides were oriented in the directions of the cardinal points. In recent years, cattle have not grazed on the sites where the plots were located. All data were collected between October 2015 and June 2017.

All trees, both live and dead, and the saplings and seedlings of all tree species in each plot were recorded. Trees were defined as individuals with a diameter at breast height $(\mathrm{dbh}) \geq 5 \mathrm{~cm}$ and saplings as individuals with a dbh $<5 \mathrm{~cm}$ and height $>200 \mathrm{~cm}$. Small seedlings were defined as individuals $<50 \mathrm{~cm}$ in height and large seedlings were defined as individuals $\geq 50$ and $\leq 200 \mathrm{~cm}$ in height. Resprouting individuals were not considered, and in some doubtful cases the soil surrounding each plant was excavated to check for independence from the nearest plants. The positions of the trees and saplings were located to the nearest centimeter using measuring tapes that were aligned with the sides of the plots, providing $\mathrm{X}$ and $\mathrm{Y}$ coordinates in a Cartesian plane. Shrub cover (\%) was measured in five line transects $(5 \mathrm{~m}$ in length) randomly located in each plot.

\section{Dendrochronological analysis}

Increment cores from all trees and species with $\mathrm{dbh} \geq 5 \mathrm{~cm}$ were extracted using Pressler increment borers (Häglof, Sweden) at 0.3-0.4 m above ground level to obtain the most accurate age for each tree (Veblen 1992), and at $0.6 \mathrm{~m}$ when the tree centers were rotten. Increment cores were mounted and sanded following the procedure established by Stokes and Smiley (1968), and the annual rings were counted using a stereomicroscope (SMZ800, Nikon, Japan). When the cores did not reach the pith, the number of rings to the center was estimated using the geometric procedure described by Duncan (1989). If the center was rotten, the rings counted in the non-rotten section of the core were considered as the minimum age for that tree. Cores were scanned at 2000 dpi resolution (Perfection V550, Epson, Japan), and tree-ring widths were measured with a $0.01 \mathrm{~mm}$ resolution on the scanned JPG images using the software CooRecorder 7.6 (Cybis, Sweden). The visual and statistical crossdating of the tree-ring width series was done and checked using the software CDendro 7.6 (Cybis, Sweden) and Cofecha (Holmes 1983), respectively. The tree-ring width series were detrended to obtain mean residual chronologies of the tree-ring width indices. First, a spline function was fitted to each tree-ring width series to obtain standardized indices which preserve the high-frequency variability potentially related to climate. Second, an autoregressive model was applied to remove the first-order temporal autocorrelation in the detrended series and generate residual indices. Third, a biweight robust mean was computed to produce residual mean chronologies for each species. Detrending residual chronologies were obtained with the package $d p l R$ (Bunn 2008) under R environment (R Development Core Team 2018).

\section{Climate data}

Climate data spanning the 1948-2019 time frame were provided by the Meteorological State Agency (AEMET) from the nearest meteorological station located $30 \mathrm{~km}$ southeast and at the same altitude as the study site (Matacán; 40 $94^{\prime} \mathrm{N}, 5^{\circ} 50^{\prime} \mathrm{W}$; $790 \mathrm{~m}$ a.s.1.). The selected climate variables were monthly total precipitation and monthly mean, minimum and maximum temperatures.

\section{Soil analysis}

Five soil subsamples per plot were taken using a soil core sampler at depths between 0 and $30 \mathrm{~cm}$. One subsample was taken in the center of the plot and four subsamples were taken $20 \mathrm{~m}$ apart from the center towards each corner of the plot. The subsamples were pooled in a single sample for structural and chemical soil analysis. The samples were air-dried and passed through a 2-mm sieve before laboratory analysis.

The $\mathrm{pH}$ was determined in distilled water (in a ratio 1:2.5) using a CRISON micropH $2001 \mathrm{pH}$ meter. Soil texture was quantified by the Robinson's pipette method after previous dispersion with sodium hexametaphosphate (Loveland and Whalley 1991). Organic carbon was determined by wet oxidation with a dichromate-sulphuric acid mixture (Walkley 1947). Residual dichromate was back titrated using ferrous sulphate. The difference in added $\mathrm{FeSO}_{4}$ compared 
with a blank titration determined the amount of easy oxidizable organic carbon (Walkley 1947). We used a conversion factor of 1.72 to convert organic carbon to organic matter (Nelson and Sommers 1996). Available $\mathrm{Ca}, \mathrm{Mg}$ and $\mathrm{K}$ were extracted using ammonium acetate $1 \mathrm{M}$ and determined by plasma ICP-MS. $\mathrm{P}$ was determined by the Bray I method, modified from Bray and Kurtz (1945).

\section{Statistical analysis}

To analyze how seedling regeneration (small seedlings, large seedlings and saplings) could be explained by soil and structural stand variables, a Redundant Analysis (RDA) was performed (Borcard et al. 2018). Previously, seedling data was transformed using a hellinger transformation, as suggested by Legendre and Gallagher (2001) for abundance data. To avoid collinearity within sets of soil and structural explanatory variables, we examined the correlation between variables and groups of variables using a hierarchical cluster analysis approach (complete linkage method). When the correlation between variables or groups of variables was greater than 0.6 , only one variable was selected, which resulted in variance inflation factors (VIF) always less than five units within the set of variables (Quinn and Keough 2002). For the soil variables we selected organic matter, $\mathrm{P}(\%), \mathrm{pH}$ and sand content (\%), and for the structural stand variables we selected basal area and tree density (Table S2, Figs. S1 and S2). Then, we performed a variation partitioning analysis (9999 random permutations) to analyze how much of the variance in seedling regeneration was explained by these variables (Borcard et al. 2018). Variation partitioning and RDA were analyzed with the vegan library (Oksanen et al. 2020) under the R environment (R Development Core Team 2018), whereas $H H$ library was used to evaluate variance inflation.

For each plot, the univariate spatial patterns of all seedlings were analysed using the O-ring statistic derived from the pair correlation function (Wiegand and Moloney 2014). The pair correlation function is the expected number of points between the largest and smallest radii of a ring of fixed width at increasing distances from an arbitrary point, divided by the intensity $k$ of the pattern (Diggle 2003; Wiegand and Moloney 2014). We used the complete spatial randomness model (CSR) implemented as a homogeneous Poisson process to determine whether the distribution of trees or saplings was random, aggregated or regular. For this univariate analysis, $\mathrm{O}(\mathrm{r})>1$ indicates that the individuals are aggregated at distances $r$, while $\mathrm{O}(\mathrm{r})<1$ means they are regularly dispersed. Additionally, the spatial relationships between seedlings and trees (of the same species and all Quercus trees pooled together) were analysed using the bivariate O-ring statistic. We used the antecedent condition as the null model, keeping the tree positions fixed whereas the seedlings were randomized using a CSR model (Wiegand and Moloney 2014). Values of $\mathrm{O}_{12}(\mathrm{r})<0$ indicate repulsion between the two classes of individuals up to distance $r$. By contrast, values of $\mathrm{O}_{12}(\mathrm{r})>0$ indicate attraction between the two classes up to distance $r$. To evaluate the significance of the spatial statistics under the null model considered, 95\% of simulated envelopes were generated using 999 Monte Carlo simulations. The twenty-fifth highest and lowest values of the 999 iterated functions were chosen to obtain the upper and lower values of the envelopes. All spatial analyses were performed using the 2014 version of the software Programita (Wiegand and Moloney 2014).

First, bootstrapped Pearson's correlation functions were calculated between the mean residual chronologies (treering index) of each tree species and monthly climatic variables (precipitation and mean, minimum and maximum temperatures). Confidence envelopes were obtained by calculating 1000 bootstrap samples and tested for significance using the 95\% percentile range method (Dixon 2001). The climatic window for these analyses spanned from the previous September (year t-1), i.e. prior to the year of tree-ring formation, up to the following September (year $\mathrm{t}$ ). This analysis was performed with the function $d c c$ implemented in the package bootRes (Zang and Biondi 2013) under R environment (R Development Core Team 2018). Second, we analyzed the trends in monthly or annual climatic data using the Kendall $\tau$ statistic with one-tail tests, as we were mainly concerned with decreasing rainfall and increasing temperature patterns over time as a result of climate change.

\section{Results}

Forest structure and regeneration dynamics of Quercus species

Woodlands showed tree densities of $95.8 \pm 29.2$ trees $\mathrm{ha}^{-1}$ and basal areas of $11.84 \pm 1.34 \mathrm{~m}^{2} \mathrm{ha}^{-1}$ 
(mean $\pm \mathrm{se}$ ), where $Q$. suber was the dominant tree species. Mean tree dbh was $29.9 \mathrm{~cm}$ (confidence interval of $24.7-36.2 \mathrm{~cm}$ at $95 \%$ level). Quercus species showed a broad and multiage structure, but with most of the trees recruiting between 1930 and 1980 (Fig. 2a). Old fields with tree remnants showed lower tree density and basal area than woodlands $\left(62.5 \pm 12.5\right.$ trees $\mathrm{ha}^{-1}, 5.20 \pm 1.95 \mathrm{~m}^{2}$ basal area ha ${ }^{-1}$, mean \pm se), and with most of the trees ( $66.7 \%$ of total trees) recruiting after 1970 (Fig. 2b). Mean tree dbh was $19.6 \mathrm{~cm}$ (confidence interval of 16.1-23.2 cm at $95 \%$ level). $Q$. suber was also the main species in the old fields with tree remnants, although $Q$. ilex dominated tree recruitment after 1990 , since the abundance of $Q$. ilex trees younger than 30 years old was four times greater than that other Quercus species (Fig. 2b).

Shrubland cover was extremely low in the old fields without tree remnants $(6.7 \pm 4.8 \%$, mean \pm se), moderate in the old fields with tree remnants $(43.0 \pm 7.2 \%)$ and high in the woodlands $(68.0 \pm 8.1 \%)$. Species of the Cistaceae family (Cistus and Helianthemum) dominated in the three land covers (Table S1).

In relation to seedling abundance, it was extremely high in the woodlands $\left(2410.4 \pm 719.8\right.$ seedlings ha ${ }^{-1}$, mean $\pm \mathrm{se}$ ) and dominated by $Q$. suber, especially in the shortest height classes (Fig. 3a). Significant differences in the mean abundance of seedlings were observed between species and height classes, with clear differences in the shortest categories but insignificant ones in the highest categories (Table 2). In the old fields with tree remnants, seedling density was moderately abundant $\left(1266.7 \pm 445.6\right.$ seedlings $\mathrm{ha}^{-1}$, mean \pm se, Fig. $3 b)$ and it varied between species and height class (Table 2). By contrast, $Q$. ilex was the only species that colonized in the old fields without tree cover, although with low densities $(33.3 \pm 10.4$ seedlings $\mathrm{ha}^{-1}$, mean \pm se, Fig. 3c). Sapling density of Quercus species was low in woodlands $(66.7 \pm 29.6$ saplings $\mathrm{ha}^{-1}$ ) and old fields with tree remnants $\left(43.7 \pm 64.9\right.$ saplings $\left.\mathrm{ha}^{-1}\right)$ and zero in old fields without tree remnants. Differences in sapling density were found between land cover types $(\mathrm{df}=2, \mathrm{~F}=7.06$, $p=0.005$ ) but no differences were found between species $(\mathrm{df}=2, \mathrm{~F}=0.62, p=0.56)$.

In woodlands and old fields with tree remnants, small seedlings of $Q$. suber showed a clumped spatial pattern, with more seedlings being encountered than expected at distances up to 8-12 $\mathrm{m}$ from each individual seedling. Additionally, $Q$. suber seedlings were associated with trees, since more seedlings than expected were found up to distances of 5-6 $\mathrm{m}$ from each tree, and a lower abundance of seedlings than expected beyond distances of 11-12 m from each tree (Table 1). Small seedlings of $Q$. ilex also presented a clumped pattern, but the clumped pattern was found at greater distances in old fields with tree remnants (up to $11 \mathrm{~m}$ ) than in woodlands (up to a) Woodlands

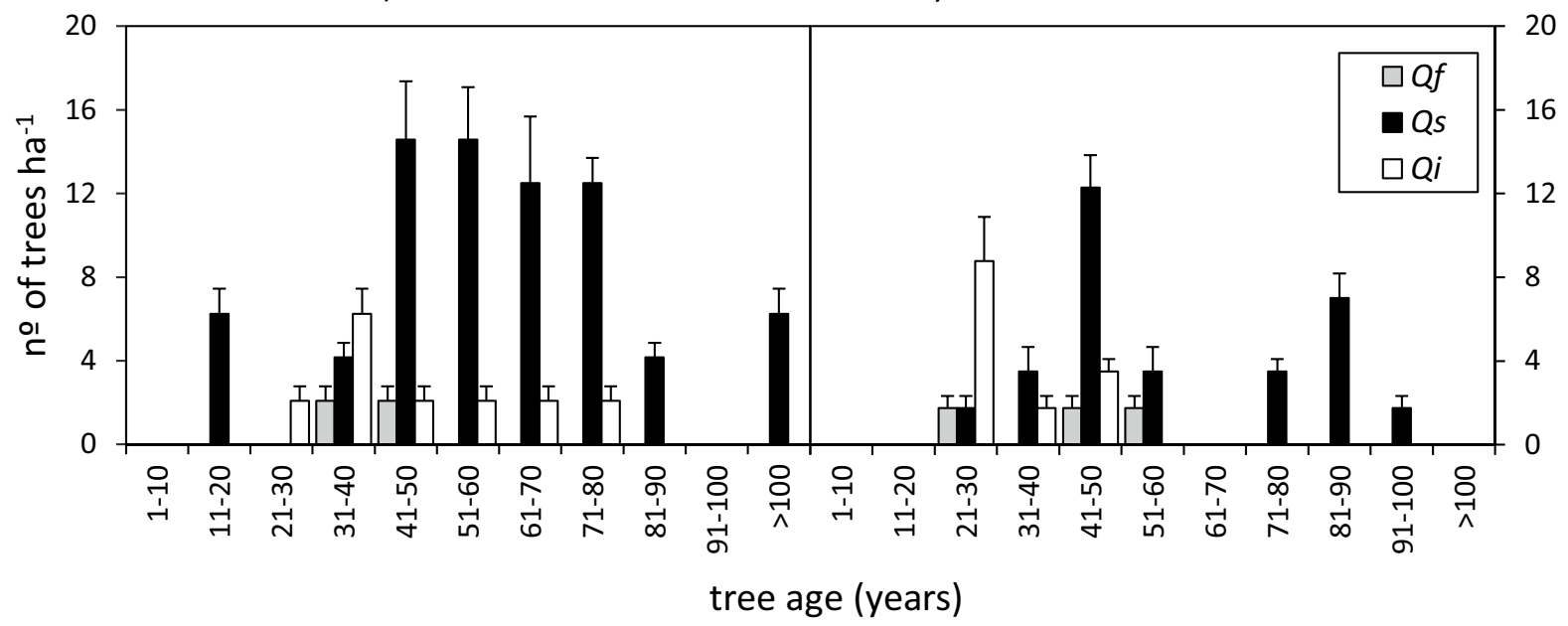

Fig. 2 Age distributions in 10-year establishment classes in woodlands (a) and old fields with tree remnants (b). Solid bars: $Q$. suber; striped bars: $Q$. ilex; open bars: $Q$. faginea 


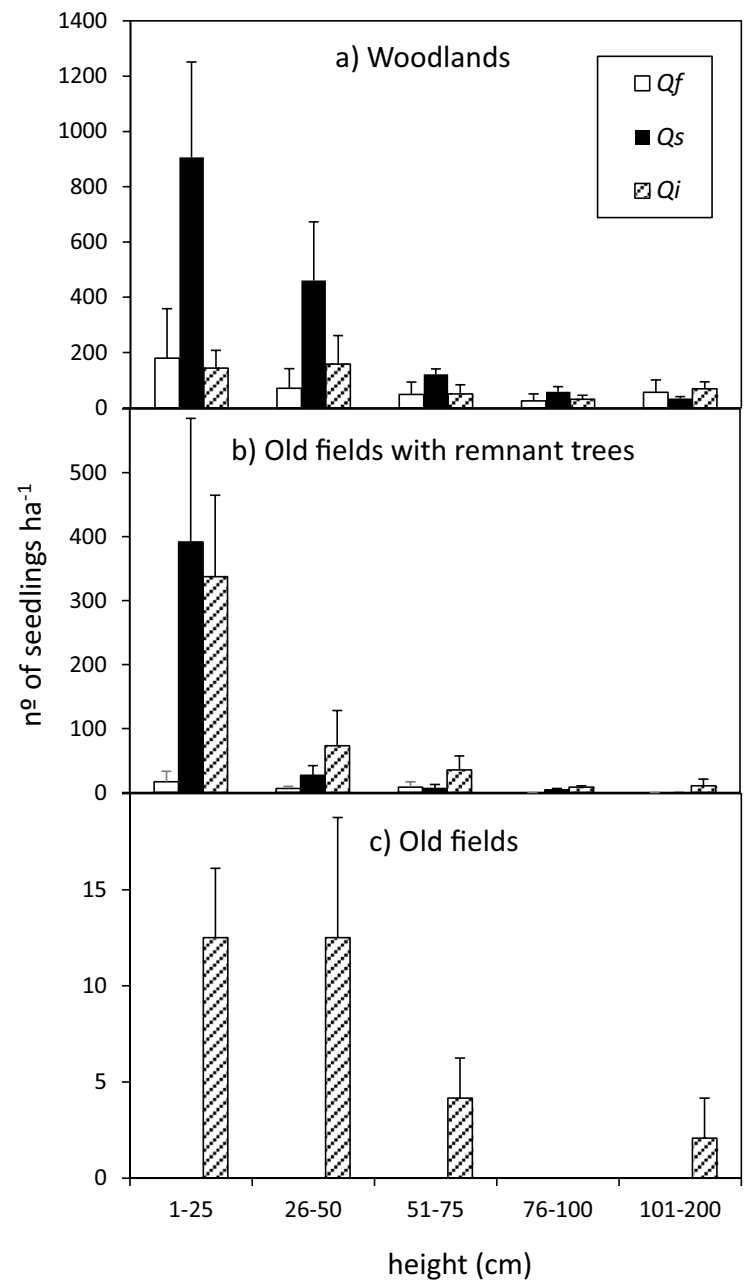

Fig. 3 Height distribution classes of Quercus seedlings in woodlands (a), old fields with tree remnants (b) and old fields without tree remnants (c). Solid bars: $Q$. suber; striped bars: $Q$. ilex; open bars: $Q$. faginea

$3 \mathrm{~m}) . Q$. ilex small seedlings were also associated with trees at short distances (up to $5 \mathrm{~m}$ in old fields with tree remnants and up to $2 \mathrm{~m}$ in woodlands), but in contrast to $Q$. suber, $Q$. ilex seedlings distributed independently from trees beyond these distances (Table 1). On the other hand, large seedlings of both $Q$. suber and $Q$. ilex mostly showed a random pattern distribution and were independently distributed from trees in woodlands whereas in old fields with tree remnants only large seedlings of $Q$. suber showed association with trees at distance of 4-7 m (Table 1).

In the RDA, the first axis represented a contrast between old fields without tree cover at the right, where only small seedlings of $Q$. ilex were present, and woodlands at the left, where small and large seedlings of $Q$. suber dominated tree regeneration (Fig. 4). Basal area, $\mathrm{pH}$ and soil organic matter showed a strong correlation with the first axis, with higher values of these three variables associated with woodlands. The second axis was related to the abundance of $Q$. faginea with regard to tree regeneration, with the sites with the higher scores in the second axis showing a higher abundance for this species (Fig. 4).

Variance partition analyses showed that soil and structural variables explained most $(81.0 \%)$ of the variance in the abundance of regeneration across sites (Fig. S3). The shared explained variance for both sets of variables was $31.6 \%$, with soil variables contributing slightly more to the unshared explained variance in seedling abundances than structural variables (soil variables: $27.1 \%, \mathrm{~F}=3.85, p=0.014$, permutations $=999$; structural stand variables: $22.3 \%, \mathrm{~F}=5.67, p=0.004$, permutations $=999$ ).

Climate-growth relationships of $Q$. suber trees

Ring growth in $Q$. suber was positively correlated with rainfall in January and June (Fig. 5a), and September temperatures (mean, maximum and minimum) and minimum winter-early spring temperatures also positively influenced ring growth (Fig. 5b-d). Monthly rainfall in January and June did not show a decreasing trend over time (Table S1), although annual rainfall significantly decreased (Table S2, Fig. S4). All mean, maximum and minimum temperatures in January, February, March and September did not show temperature increases over time, except for the minimum temperature in September (Table S2).

\section{Discussion}

Regeneration dynamics of Quercus species

Our results indicate that remnant oak trees are great accelerators of forest recovery after cultivation abandonment. Old fields with tree remnants boost oak regeneration almost 40-fold in comparison to old fields without trees, and woodlands show a 2 -fold increase in oak regeneration in comparison to old fields with tree remnants. Tree basal area and density were strongly and positively correlated with 
Table 1 Results of the O-ring statistic for the univariate and bivariate analyses. Statistical significance at $95 \%$ simulated envelopes for the univariate analyses (grey: random pattern; black: clumped pattern; white: regular pattern) and for the bivariate analyses (grey: independence pattern; black: attraction pattern; white: repulsion pattern)

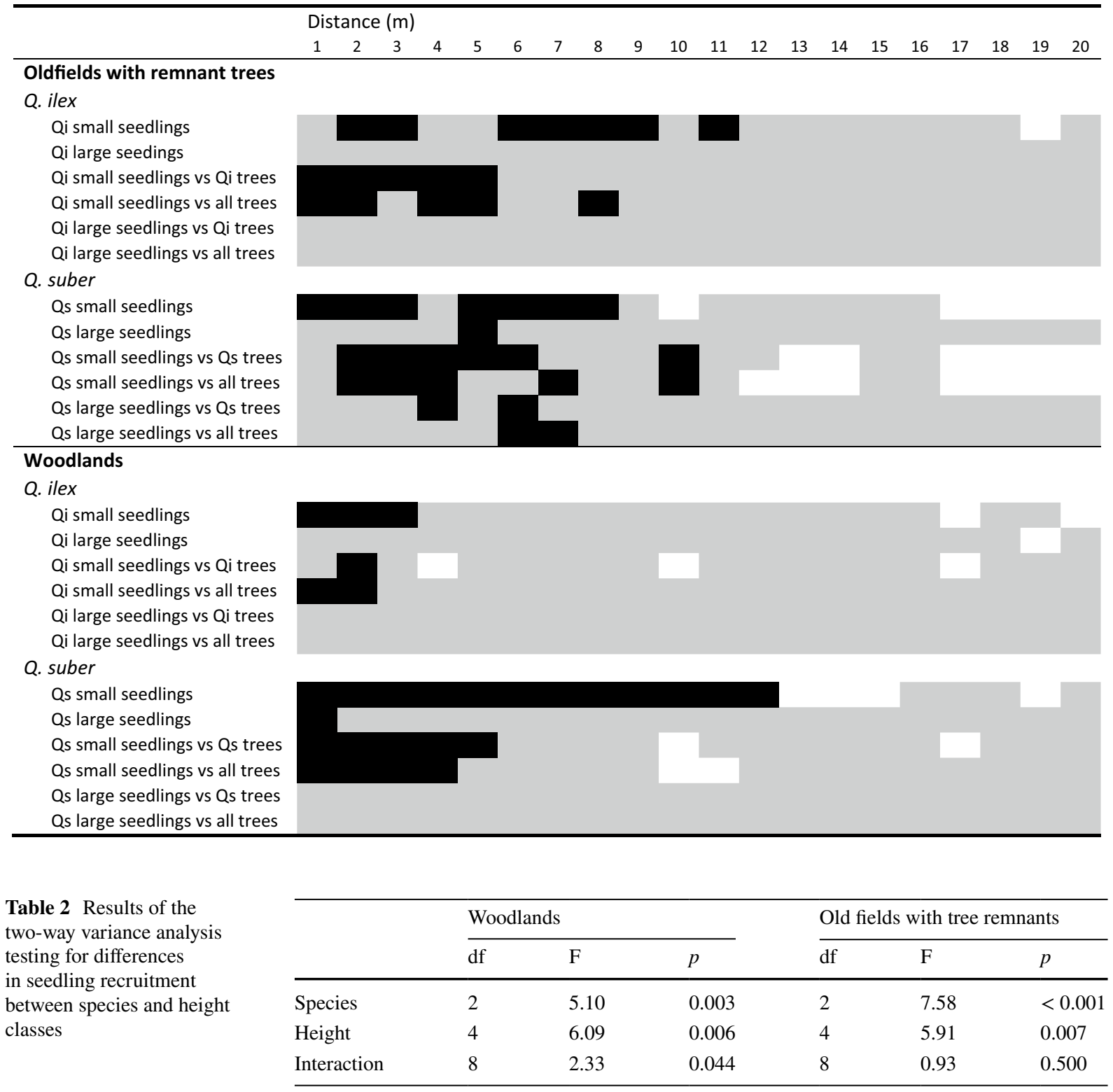

the gradient of seedling density. Additionally, the spatial analysis of small seedlings of $Q$. suber and Q.ilex, which accounted for most seedling abundance (71.6\%), showed a clustered pattern associated with Quercus trees in both woodlands and old fields with tree remnants, although at shorter distances in the case of $Q$. ilex than in $Q$. suber. Two types of mechanism likely explain these patterns. First, acorns are heavy fruits with limited dispersal, where most of the acorns produced only reach areas situated close to the parent trees (Pulido and Díaz 2005; Acácio et al. 2007; Pausas et al. 2009b). Second, facilitation caused by tree shading are key effects in Mediterranean environments (Caldeira et al. 2014), where drought stress and summer seedling survival during the first years of establishment is considered one of the main bottlenecks in Quercus regeneration (Pulido and Díaz 2005; Silla and Escudero 2004, 
Fig. 4 Redundant Analysis (RDA) showing differences in plots in relation to regeneration abundance of seedlings and saplings. The sizes of the circles are proportional to abundance of tree regeneration (seedlings plus saplings) in each plot. Regeneration codes are Qs: Q. suber; Qi: Q. ilex; Qf: $Q$. faginea; sa: saplings; 1s: large seedlings; ss: small seedlings. Vectors showed structural (BA: basal area; TD: trees density) and soil (OM: organic matter; $\mathrm{pH}$; P: phosphorus; sand: sand content) variables

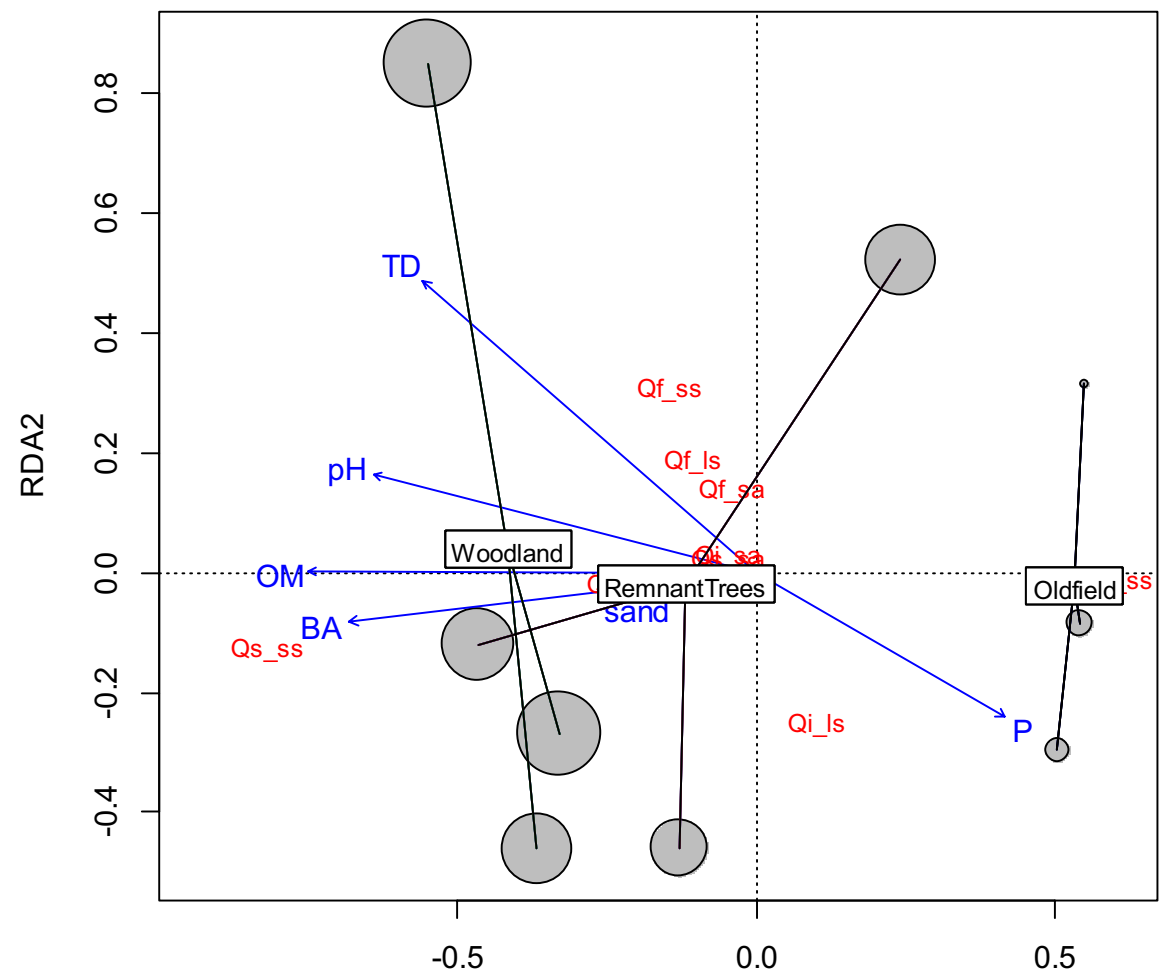

RDA1
Smit et al. 2009, Pérez-Ramos et al. 2012, Costa et al. 2017). Furthermore, the presence of tree cover showed a strong influence over soil parameters with higher concentrations of organic matter, $\mathrm{N}$, exchangeable cations $\left(\mathrm{K}^{+}, \mathrm{Ca}^{2+}, \mathrm{Mg}^{2+}\right)$ and slightly less acidic soils. The deep root system of $Q$. suber trees uptakes and pumps cations, which affect the soil by significantly improving their nutrient availability throughout litterfall production and decomposition (Serrasolses et al. 2009; Rossetti et al. 2015). The results of the variance partitioning showed that both stand structural and soil parameters explain a significant amount of the shared variation in the amount of regeneration of Quercus species, which makes sense since the influence of trees on soil characteristics are spatially correlated. However, soil variables explain a significant amount of the variance (27.1\%) not explained by structural stand variables and so are important for understanding the differences found in Quercus regeneration between plots. Among the soil variables, organic matter content summarizes most information on nutrient availability with which it is strongly correlated. Also, organic matter is also directly involved in improving soil water retention in abandoned cultivars, especially in soils with high sand content (Rawls et al. 2003; Costa et al. 2017). On the other hand, low seedling density and the lack of sapling recruitment indicate that succession was considerably arrested in the plots without tree remnants two to three decades after cultivation abandonment. Similar trends have been observed in other studies, where 45 years after abandonment Cistus-dominated shrublands prevailed with scarce or absent oak recruitment (Acácio and Holmgren 2014). Cistus-dominated shrublands, as well as acorn availability and drought stress, exert competition and inhibition effects over Quercus recruitment and appear as highly resilient systems (Pérez-Devesa et al. 2008; Rolo and Moreno 2011; Acácio and Holmgren 2014). However, without ruling out any inhibitory effects, shrub cover was quite low in open plots and vegetation was dominated by annual herbaceous species, likely due to low rainfall combined with high sand and low organic soil contents that exacerbated hydric stress (Fernández Alés et al. 1993; Rawls et al. 2003; Nunes et al. 2017). 
Fig. 5 Climate-growth associations calculated for $Q$. suber trees. The bars indicate the mean Pearson correlation coefficients (error bars show 95\% confidence intervals) calculated between ring-width indices and monthly climatic variables. The temporal window of analyses comprises the hydrological year from October of the previous year to September of the current year ( $\mathrm{x}$ axes). Significant correlations are indicated by bars filled with dark grey color a) Monthly rainfall

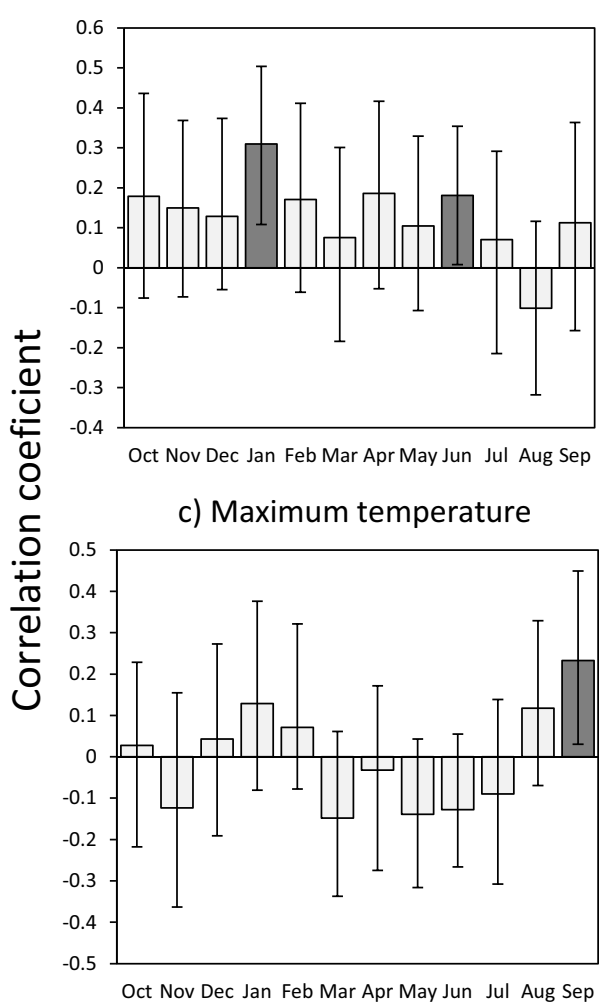

b) Mean temperature

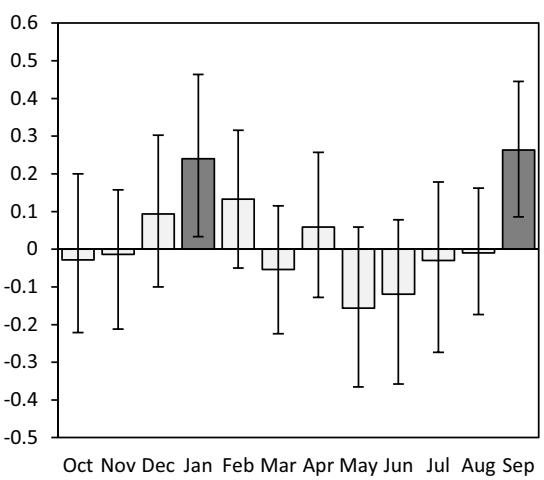

d) Minimum temperature

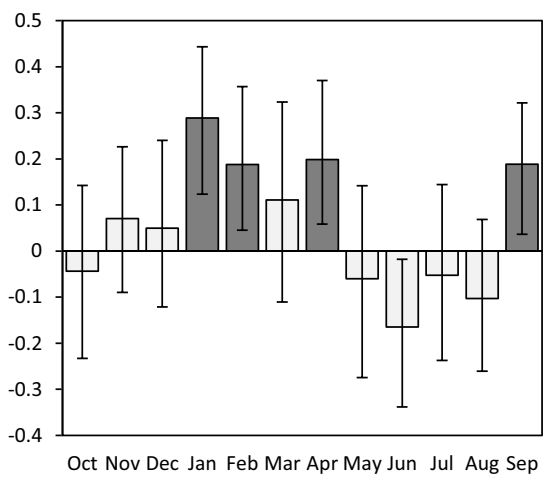

Months

Q. ilex was the only tree species successfully recruiting in the open old fields, although slowly and with low densities, despite $Q$. suber being the dominant tree species in the landscape with respect to density and basal area. Two processes are likely involved in the success of $Q$. ilex over other Quercus species in the open plots. First, although Quercus species share the same animal dispersers, most studies have shown that acorns from $Q$. ilex are preferred over other Quercus species by the main oak disperser the Eurasian jay (Garrulus glandarius) and by small rodents (Pons and Pausas 2007a, c; del Arco et al. 2018). Since the Eurasian jay is a forest species that has never been detected in the study area, mice species are the main candidates for acorn dispersal. Pilferage rates are reduced by caching the seeds preferentially outside the canopies of scattered trees, increasing the survival of cached acorns in open areas (Muñoz and Bonal 2011). Nevertheless, absence of facilitative shrub cover (by Cytisus spp. or other facilitative species) likely limited successful recruitment causing a low density of $Q$. ilex seedlings in the open plots (Pulido and Díaz 2005; Smit et al. 2009; Rolo and Moreno 2011). Second, although both evergreen species, $Q$. suber and $Q$. ilex, are well adapted to the summer drought of the Mediterranean climate (Mediavilla and Escudero 2003; González-Rodríguez et al. 2011; San-Eufrasio et al. 2020), previous studies have shown a higher survival rate and performance for Q.ilex seedlings than for Q.suber under high water stress (Plieninger et al. 2010; González-Rodríguez et al. 2011). For instance, $Q$. ilex has lower conductance and lower maximum transpiration rates than $Q$. suber, which delays leaf desiccation and decreases growth suppression in $Q$. ilex under water limitation (Mediavilla and Escudero 2003; Caldeira et al. 2014; San-Eufrasio et al. 2020). On the other hand, Quercus large seedlings showed a random spatial pattern independent of the trees, highlighting that tree cover is only a limiting factor during the first steps of seedling establishment. These changes in the spatial pattern with ontogenetic development support previous findings that suggest that the positive effects 
of shaded microhabitats are reversed for seedling development (Pérez-Ramos et al. 2010; Pausas et al. 2009b). In $Q$. suber and $Q$. ilex, seedling establishment and survival are improved under shade (Espelta et al. 1995; Pausas et al. 2009b; Smit et al. 2009; PérezRamos et al. 2012). However, it has been also shown that low light suppresses growth, that these species establish 'seedling banks' under dense tree cover and that more open canopy conditions are required for saplings and trees to develop (Espelta et al. 1995; Pausas et al. 2009b; Pérez-Ramos et al. 2010, 2012).

We also found significant differences in the regeneration densities of $Q$. suber, $Q$. ilex, $Q$. faginea, with the abundance of $Q$. suber strongly correlated with the basal area and tree density of stands. In woodlands, $Q$. suber showed a greater number of small seedlings than $Q$. ilex, but the differences in seedling abundance disappeared in the tallest height categories. In the old fields with tree remnants, $Q$. ilex and $Q$. suber showed similar seedling densities, and although the interaction was not significant, the abundance of $Q$. ilex large seedlings was 5-6 fold higher than that of $Q$. suber. These results indicate that in both woodlands and old fields with tree remnants $Q$. ilex has a higher seedling survival rate and more likely to reach the sapling stage, probably due to their higher tolerance to shade (Sevilla 2008), and specially, to their greater tolerance to hydric stress during the summer (Plieninger et al. 2010; GonzálezRodríguez et al. 2011; San-Eufrasio et al. 2020). Thus, although $Q$. suber trees dominate the landscape of our study area, the results indicate that $Q$. ilex can produce a greater number of young trees as compared to $Q$. suber, owing to the better performance of $Q$. ilex seedlings. Only in woodlands can $Q$. suber partially compensate for their lower performance and survival, producing a higher number of seedlings. Conversely, the deciduous $Q$. faginea present the lowest abundance, especially in the old fields (with or without tree remnants), which is in line with its lower tolerance to drought compared to evergreen species (Silla and Escudero 2004; González-Rodríguez et al. 2011; San-Eufrasio et al. 2020).

\section{Climate-growth relationships of $Q$. suber trees}

Analysis of the impact of climatic conditions on the tree-ring growth of $Q$. suber is challenging due to the difficulty in identifying ring boundaries in trees being managed for cork extraction (Costa et al. 2003). Only two previous studies have reported successful tree ring chronologies involving $Q$. suber in the Mediterranean region (Costa et al. 2003; Zribi et al. 2016) that have been complemented with short chronologies from cork growth-rings (Caritat et al. 1996; Costa et al. 2016; Leite et al. 2019). As shown in these studies, winter and spring precipitation exerted a large positive effect on treering growth due to the replenishment of soil water reserves before the onset of the favorable growing season (Costa et al. 2001; Jovellar et al. 2010; Costa et al. 2016; Zribi et al. 2016; Leite et al. 2019). In our study site, $Q$. suber showed the latest leaf emergence of all coexisting Quercus species, with budbreak and emergence of the new leaf cohort occurring between the end of May and the beginning of June (del Río et al. 2015). However, in relation to other studies where temperature has been found to have an insignificant or negative effect over cork or ring growth (Caritat et al. 1996; Costa et al. 2001; Zribi et al. 2016), in our study site, the mean and minimum temperatures during winter and/or spring and the mean and maximum temperatures during September exerted a positive influence on tree growth. This is consistent with the cold temperature conditions occurring in winter and early spring in our study area, located at the leading temperature edge of its distribution limits in the Iberian Peninsula. The large vessels in oak trees are very sensitive to winter embolisms caused by freezing temperatures, and in spring the reactivation of growth is greatly dependent on hydraulic conductivity recovery (Hacke and Sauter 1996; Lebourgeois et al. 2004). This highlights the importance of mild winter-early spring temperatures on $Q$. suber tree growth in the "cold leading edge" of its distribution. However, although winter temperatures are a limiting factor and warming has room for net positive effects on tree growth (SánchezSalguero et al. 2015), climatic data did not reveal a significant temperature increase during winter and early spring in this study site. On the other hand, minimum temperatures during September have significantly increased during the last decades and have had a positive impact on tree growth by most likely extending the favorable weather (Marqués et al. 2018). However, the positive effect of an extended growing season in early autumn can be counteracted by a decrease in rainfall, especially in the study area 
where annual rainfall is also in the lower edge of $Q$. suber distribution limits, as has also been recently observed in Mediterranean forest at the limits of species distribution (Madrigal-González et al. 2018; Marqués et al. 2018). Although no significant decreasing trends were found in the more critical months, there is a decreasing trend in mean annual rainfall, so more detailed studies will be needed to understand the combined effects of temperature and rainfall on tree growth within future climate change scenarios.

\section{Conclusions}

Regeneration dynamics were strongly modeled by the presence and density of tree cover in the fragmented landscape in the cold and dry edge of $Q$. suber distribution. Tree cover affects seedling abundance differently likely through both direct (acorn availability and shading) and indirect (improving nutrient availability and water retention in soils) mechanisms. The stress tolerant species $Q$. ilex was the only species found to recruit in open old fields decades after being abandoned. The presence of isolated tree remnants in old fields allowed the recruitment of $Q$. suber, but $Q$. ilex had a higher abundance of large seedlings and young trees; only in woodlands did both species show similar recruitment success. These results indicate that $Q$. ilex is regenerating more abundantly in this landscape owing to its better performance compared to $Q$. suber, even though the latter species is the dominant tree in our study area. Dominance of $Q$. suber can be partly explained by higher economic profits in relation to other Quercus species (Urbieta et al. 2008; Acácio et al. 2017). However, in the absence of management, the abundance $Q$. ilex trees would increase, and the transition to a more balanced mixed evergreen forests would be predicted. This transition would be accelerated in a warmer and drier climate were the establishment of $Q$. suber would be impaired in patches of low tree cover and restricted to the more suitable woodlands. On the other hand, the climate-tree growth relationship of $Q$. suber showed greater uncertainty in predicting tree growth and productivity under climate change scenarios involving increasing temperatures and less rainfall. In the cold leading edge of $Q$. suber distribution, higher temperatures were found to have a positive effect on tree ring-growth, especially during winter/ early spring and early autumn. By contrast, winter and spring rainfall recharges water soil reserves promoting tree growth during the favorable season and increasing dryness due to climate change can counteract the positive effects of temperature.

Acknowledgements This study was funded by project SA013G19 from "Junta de Castilla y León" and by research grants awarded for final projects directed in the Master's degree in Biology and Conservation of Biodiversity at the University of Salamanca, Spain. We are grateful to Milena Holmgren and one anonymous reviewer for their helpful comments. Emma Keck kindly corrected the English.

Authors' contributions Conceptualization: Fernando Silla; Methodology: Carmen Ureña, Diego Navarro, Valentín Herrera, Pilar Alonso-Rojo, Fernando Silla; Formal analysis and investigation: Carmen Ureña, Diego Navarro, Valentín Herrera, Jorge Montero-Muñoz and Fernando Silla; Writing - original draft preparation: Jorge Montero-Muñoz and Fernando Silla; Writing - review and editing: Carmen Ureña, Diego Navarro, Valentín Herrera, Pilar Alonso-Rojo, Héctor HernándezAlonso, Ma Fernanda Cepeda, Luis Carlos Jovellar, Belén Fernández-Santos.

Funding This study was funded by project SA013G19 from "Junta de Castilla y León" and by research grants awarded for final projects directed in the Master's degree in Biology and Conservation of Biodiversity at the University of Salamanca, Spain.

Data availability Raw data will be available in the Open Science Framework repository upon acceptance.

Code availability Not applicable.

\section{Declarations}

Ethics approval Not applicable.

Consent to participate Not applicable.

Consent for publication All authors consent the publication of this manuscript upon acceptance.

Conflicts of interest/Competing interests Authors declare no conflicts of interest

Open Access This article is licensed under a Creative Commons Attribution 4.0 International License, which permits use, sharing, adaptation, distribution and reproduction in any medium or format, as long as you give appropriate credit to the original author(s) and the source, provide a link to the Creative Commons licence, and indicate if changes were made. The 
images or other third party material in this article are included in the article's Creative Commons licence, unless indicated otherwise in a credit line to the material. If material is not included in the article's Creative Commons licence and your intended use is not permitted by statutory regulation or exceeds the permitted use, you will need to obtain permission directly from the copyright holder. To view a copy of this licence, visit http://creativecommons.org/licenses/by/4.0/.

\section{References}

Acácio V, Holmgren M (2014) Pathways for resilience in Mediterranean cork oak land use systems. Ann For Sci 71:513. https://doi.org/10.1007/s13595-012-0197-0

Acácio V, Holmgren M, Jansen PA, Schrotter O (2007) Multiple recruitment limitation causes arrested auccession in Mediterranean cork oak systems. Ecosystems 10:12201230. https://doi.org/10.1007/s10021-007-9089-9

Acácio V, Dias FS, Catry FX, Rocha M, Moreira F (2017) Landscape dynamics in Mediterranean oak forests under global change: understanding the role of anthropogenic and environmental drivers across forest types. Glob Change Biol 23:1199-1217. https://doi.org/10.1111/gcb. 13487

Barbero M, Bonin G, Loisel R, Quézel P (1990) Changes and disturbances of forest ecosystems caused by human activities in the western part of the Mediterranean Basin. Vegetatio 87:151-173. https://doi.org/10.1007/BF00042952

Blanco E, Casado M, Costa M, Escribano R, García M, Génova M, Gómez A, Gómez F, Moreno JC, Morla C, Regato P, Sainz H (1997) Los bosques ibéricos: una interpretación geobotánica. Planeta, Barcelona

Borcard D, Gillet F, Legendre P (2018) Numerical ecology with R. Springer International Publishing, Cham. https:// doi.org/10.1007/978-3-319-71404-2

Branco M, Branco C, Merouani H, Almeida MH (2002) Germination success, survival and seedling vigour of Quercus suber acorns in relation to insect damage. For Ecol Manag 166:159-164. https://doi.org/10.1016/S0378-1127(01) 00669-7

Bray RH, Kurtz LT (1945) Determination of total organic and available forms of phosphorus in soils. Soil Sci 59:39-45

Bugalho M, Plieninger T, Aronson J, Ellatifi M, Gomes Crespo D (2009) Open woodlands: a diversity of uses (and overuses). In: Aronson J, Pereira JS, Pausas JG (eds) Cork oak woodlands on the edge. Island Press, Washington DC, pp $33-47$

Bunn AG (2008) A dendrochronology program library in $R$ (dplR). Dendrochronologia 26:115-124. https://doi.org/10. 1016/j.dendro.2008.01.002

Caldeira MC, Ibáñez I, Nogueira C, Bugalho MN, Lecomte X, Moreira A, Pereira JS (2014) Direct and indirect effects of tree canopy facilitation in the recruitment of Mediterranean oaks. J Appl Ecol 51:349-358. https://doi.org/10. 1111/1365-2664.12189

Camisón A, Miguel R, Marcos JL, Revilla J, Tardáguila M, Hernández D, Lakicevic M, Jovellar L, Silla F (2015) Regeneration dynamics of Quercus pyrenaica Willd. In the central system (Spain). For Ecol Manag 343:42-52. https://doi.org/10.1016/j.foreco.2015.01.023
Caritat A, Molinas M, Gutiérrez E (1996) Annual cork-ring width variability of Quercus suber L. in relation to temperature and precipitation (Extremadura, southwestern Spain). For Ecol Manag 86:113-120. https://doi.org/10. 1016/S0378-1127(96)03787-5

Carrión JS, Parra I, Navarro C, Munuera M (2000) Past distribution and ecology of the cork oak (Quercus suber) in the Iberian Peninsula: a pollen-analytical approach. Divers Distrib 6:29-44. https://doi.org/10.1046/j.1472-4642. 2000.00070.x

Chauchard S, Carcaillet C, Guibal F (2007) Patterns of landuse abandonment control tree-recruitment and forest dynamics in Mediterranean mountains. Ecosystems 10:936-948. https://doi.org/10.1007/s10021-007-9065-4

Costa A, Pereira H, Oliveira A (2001) Dendroclimatological approach to diameter growth in cork-oak adult trees under cork production. Trees 15:438-443. https://doi.org/10. 1007/s004680100119

Costa A, Pereira H, Oliveira A (2003) Variability of radial growth in cork oak adult trees under cork production. For Ecol Manag 175:239-246. https://doi.org/10.1016/S03781127(02)00145-7

Costa A, Barbosa I, Roussado C, Graça J, Spiecker H (2016) Climate response of cork growth in the Mediterranean oak (Quercus suber L.) woodlands of southwestern Portugal. Dendrochronologia 38:72-81. https://doi.org/10.1016/j. dendro.2016.03.007

Costa A, Villa S, Alonso P, García-Rodríguez JA, Martín FJ, Martínez-Ruiz C, Fernández-Santos B (2017) Can native shrubs facilitate the early establishment of contrasted cooccurring oaks in Mediterranean grazed areas? J Veg Sci 28:1047-1056. https://doi.org/10.1111/jvs. 12550

Del Arco JM, Beltrán D, Martínez-Ruiz C (2018) Risk for the natural regeneration of Quercus species due to the expansion of rodent species (Microtus arvalis). Behav Ecol Sociobiol 72:160

Del Río T, Mediavilla S, Silla F, Escudero A (2015) Differences in the environmental control of leaf senescence of four Quercus species coexisting in a Mediterranean environment. Forest Syst 24:e027. https://doi.org/10.5424/fs/ 2015242-07263

Diggle PJ (2003) Statistical analysis of spatial point patterns. Arnold, London

Dixon PM (2001) Bootstrap resampling. In: El-Shaarawi AH, Piegorsch WW (eds) The encyclopedia of Environmetrics. Wiley, New York

Duncan RP (1989) An evaluation of errors in tree age estimates based on increment cores in Kahikatea (Dacrycarpus dacrydioides). N Z Nat Sci 16:31-37

Espelta JM, Riba M, Retana J (1995) Patterns of seedling recruitment in West-Mediterranean Quercus ilex forests influenced by canopy development. J Veg Sci 6:465-472. https://doi.org/10.2307/3236344

Fernández Alés R, Laffarga JM, Ortega F (1993) Strategies in Mediterranean grassland annuals in relation to stress and disturbance. J Veg Sci 4:313-322. https://doi.org/10.2307/ 3235589

Gómez JM, García D, Zamora R (2003) Impact of vertebrate acorn- and seedling predators on a Mediterranean Quercus pyrenaica forest. For Ecol Manag 180:125-134. https://doi.org/10.1016/S0378-1127(02)00608-4 
González-Rodríguez V, Villar R, Casado R, Suárez-Bonnet E, Quero JL, Navarro-Cerrillo RM (2011) Spatio-temporal heterogeneity effects on seedling growth and establishment in four Quercus species. Ann For Sci 68:1217-1232. https://doi.org/10.1007/ s13595-011-0069-z

Guerra Velasco JC (2015) Apropiación y explotación del corcho en Valdelosa (Salamanca) 1835-1975. Hist Agraria 65:95-120

Hacke U, Sauter JJ (1996) Xylem dysfunction during winter and recovery of hydraulic conductivity in diffuse-porous and ring-porous trees. Oecologia 105:425-439. https:// doi.org/10.1007/BF00330005

Holmes RL (1983) Computer-assisted quality control in treering dating and measurement. Tree-Ring Bull 43:69-78

Houston Durrant T, de Rigo D, Caudullo G (2016) Quercus suber in Europe: distribution, habitat, usage and threats. In: San-Miguel-Ayanz J, de Rigo D, Caudullo G, Houston Durrant T, Mauri A (eds) European atlas of forest tree species. Publ. Off. EU, Luxembourg, pp e01ff11+

Ibáñez B, Gómez-Aparicio L, Stoll P, Ávila JM, Pérez-Ramos IM, Marañón T (2015) A neighborhood analysis of the consequences of Quercus suber decline for regeneration dynamics in Mediterranean forests. PLoS One 10:e0117827. https://doi.org/10.1371/journal.pone.01178 27

Jovellar LC, Blanco A, Santos F (2010) Influence of the soil water holding capacity on the potential distribution of forest species. A case study: the potential distribution of cork oak (Quercus suber L.) in Central-Western Spain. Eur J Forest Res 129:111-117. https://doi.org/10.1007/ s10342-008-0251-5

Kovats RS, Valentini R, Bouwer LM, Georgopoulou E, Jacob D, Martin E, Rounsevell M, Soussana MF (2014) Europe. In: Barros VR, Field CB, Dokken DJ, Mastrandrea MD, Mach KJ, Bilir TE, Chatterjee M, Ebi KL, Estrada YO, Genova RC, Girma B, Kissel ES, Levy AN, MacCracken S, Mastrandrea PR, White LL (eds) Climate change 2014: Impacts, adaptation, and vulnerability. Part B: Regional aspects. Contribution of working group II to the fifth assessment report of the intergovernmental panel on climate change. Cambridge University Press, Cambridge, pp 1267-1326

Lebourgeois F, Cousseau G, Ducos Y (2004) Climate-treegrowth relationships of Quercus petraea Mill. stand in the Forest of Bercé ("Futaie des Clos", Sarthe, France). Ann For Sci 61:361-372. https://doi.org/10.1051/forest:20040 29

Legendre P, Gallagher ED (2001) Ecologically meaningful transformations for ordination of species data. Oecologia 129:271-280. https://doi.org/10.1007/s004420100716

Leite C, Oliveira V, Lauw A, Pereira H (2019) Cork rings suggest how to manage Quercus suber to mitigate the effects of climate changes. Agric For Meteorol 266-267:12-19. https://doi.org/10.1016/j.agrformet.2018.11.032

Loveland PJ, Whalley WR (1991) Particle size analysis. In: Smith KA, Mullis CE (eds) Soil analysis: physical methods. Marcel Dekker, New York, pp 271-328

Madrigal-González J, Andivia E, Zavala MA, Stoffel M, Calatayud J, Sánchez-Salguero R, Ballesteros-Cánovas J (2018) Disentangling the relative role of climate change on tree growth in an extreme Mediterranean environment. Sci
Total Environ 642:619-628. https://doi.org/10.1016/j.scito tenv.2018.06.064

Magri D, Fineschi S, Bellarosa R, Buonamici A, Sebastiani F, Schirone B, Simeone MC, Vendramin GG (2007) The distribution of Quercus suber chloroplast haplotypes matches the palaeogeographical history of the western Mediterranean. Mol Ecol 16:5259-5266. https://doi.org/10.1111/j. 1365-294X.2007.03587.x

Marqués L, Madrigal-González J, Zavala MA, Camarero JJ, Hartig F (2018) Last century forest productivity in a managed dry-edge scots pine population: the two sides of climate warming. Ecol Appl 28:95-105. https://doi.org/10. 1002/eap.1631

Mediavilla S, Escudero A (2003) Stomatal responses to drought at a Mediterranean site: a comparative study of co-occurring woody species differing in leaf longevity. Tree Physiol 23:987-996. https://doi.org/10.1093/treep hys/23.14.987

Muñoz A, Bonal R (2011) Linking seed dispersal to cache protection strategies. J Ecol 99:1016-1025. https://doi.org/10. 1111/j.1365-2745.2011.01818.x

Nelson DW, Sommers LE (1996) Total carbon, organic carbon, and organic matter. In: Sparks DL, et al. (eds) methods of soil analysis. Part 3. Chemical methods, SSSA book series no. 5, SSSA and ASA, Madison, pp 961-1010

Nunes A, Köbela M, Pinho P, Matos P, de Bello F, Correia O, Branquinho C (2017) Which plant traits respond to aridity? A critical step to assess functional diversity in Mediterranean drylands. Agric For Meteorol 239:176-184. https://doi.org/10.1016/j.agrformet.2017.03.007

Oksanen J, Blanchet FG, Friendly M, Kindt R, Legendre P, McGlinn D, Minchin PR, O’Hara RB, Simpson GL, Solymos P, Stevens MHH, Szoecs E, Wagner H (2020) Vegan: community ecology package. R package version $2.5-7$. https://CRAN.R-project.org/package=vegan. Accessed 20 Nov 2020

Ovando P, Campos P, Oviedo JL, Montero G (2009) Costbenefit analysis of cork oak woodland afforestation and facilitated natural regeneration in Spain. In: Aronson J, Pereira JS, Pausas JG (eds) Cork oak woodlands on the edge. Island Press, Washington DC, pp 177-188

Pausas JG, Pereira JS, Aronson J (2009a) The tree. In: Aronson J, Pereira JS, Pausas JG (eds) Cork oak woodlands on the edge. Island Press, Washington DC, pp 11-24

Pausas JG, Marañón T, Caldeira M, Pons J (2009b) Natural regeneration. In: Aronson J, Pereira JS, Pausas JG (eds) Cork oak woodlands on the edge. Island Press, Washington DC, pp 115-124

Pereira JS, Vaz Correia A, Joffre R (2009) Facing climate change. In: Aronson J, Pereira JS, Pausas JG (eds) Cork oak woodlands on the edge. Island Press, Washington DC, pp 219-226

Pérez-Devesa M, Cortina J, Vilagrosa A, Vallejo R (2008) Shrubland management to promote Quercus suber L. establishment. For Ecol Manag 255:374-382. https://doi. org/10.1016/j.foreco.2007.09.074

Pérez-Ramos IM, Gómez-Aparicio L, Villar R, García LV, Marañón T (2010) Seedling growth and morphology of three oak species along field resource gradients and seed mass variation: a seedling age-dependent response. J Veg 
Sci 21:419-437. https://doi.org/10.1111/j.1654-1103. 2009.01165. $\mathrm{x}$

Pérez-Ramos IM, Urbieta IR, Zablaa MA, Marañón T (2012) Ontogenetic conflicts and rank reversals in two Mediterranean oak species: implications for coexistence. J Ecol 100:467-477. https://doi.org/10.1111/j.1365-2745.2011. 01912.x

Plieninger T, Rolo V, Moreno G (2010) Large-scale patterns of Quercus ilex, Quercus suber, and Quercus pyrenaica regeneration in Central-Western Spain. Ecosystems 13:644-660. https://doi.org/10.1007/s10021-010-9345-2

Pons J, Pausas JG (2006) Oak regeneration in heterogeneous landscapes: the case of fragmented Quercus suber forests in the eastern Iberian Peninsula. For Ecol Manag 231:196-204. https://doi.org/10.1016/j.foreco.2006.05. 049

Pons J, Pausas JG (2007a) Rodent acorn selection in a Mediterranean oak landscape. Ecol Res 22:535-541. https:// doi.org/10.1007/s11284-006-0053-5

Pons J, Pausas JG (2007b) Acorn dispersal estimated by radio-tracking. Oecologia 153:903-911. https://doi.org/ 10.1007/s00442-007-0788-x

Pons J, Pausas JG (2007c) Not only size matters: acorn selection by the European jay (Garrulus glandarius). Acta Oecol 31:353-360. https://doi.org/10.1016/j.actao.2007. 01.004

Pulido FJ, Díaz M (2005) Regeneration of a Mediterranean oak: a whole-cycle approach. Ecoscience 12:92-102. https://doi.org/10.2980/i1195-6860-12-1-92.1

Quinn GP, Keough MJ (2002) Experimental design and data analysis for biologists. Cambridge University Press, New York

R Development Core Team (2018) R: A language and environment for statistical computing. R Foundation for Statistical Computing, Vienna, Austria. ISBN 3-90005107-0, URL http://www.R-project.org. Accessed 14 Sept 2020

Rawls WJ, Pachepskyb YA, Ritchie JC, Sobeckic TM, Bloodworth H (2003) Effect of soil organic carbon on soil water retention. Geoderma 116:61-76. https://doi. org/10.1016/S0016-7061(03)00094-6

Rolo V, Moreno G (2011) Shrub species affect distinctively the functioning of scattered Quercus ilex trees in Mediterranean open woodlands. For Ecol Manag 261:17501759. https://doi.org/10.1016/j.foreco.2011.01.028

Rossetti I, Bagella S (2014) Mediterranean Quercus suber wooded grasslands risk disappearance: new evidences from Sardinia (Italy). For Ecol Manag 329:148-157. https://doi.org/10.1016/j.foreco.2014.06.010

Rossetti I, Bagella S, Cappai C, Caria MC, Lai R, Roggero PP, da Silva PM, Sousa JP, Querner P, Seddaiu G (2015) Isolated cork oak trees affect soil properties and biodiversity in a Mediterranean wooded grassland. Agric Ecosyst Environ 202:203-216. https://doi.org/10.1016/j. agee.2015.01.008

Sánchez-Palomares O, Jovellar LC, Sarmiento LA, Rubio A, Gandullo JM (2007) Las estaciones ecológicas de los alcornocales españoles. Monografías INIA: Serie forestal. INIA, Madrid

Sánchez-Salguero R, Camarero JJ, Hevia A, MadrigalGonzález J, Linares JC, Ballesteros-Canovas JA,
Sánchez-Miranda A, Alfaro-Sánchez R, SangüesaBarreda G, Galván JC, Gutiérrez E, Génova M, Rigling A (2015) What drives growth of scots pine in continental Mediterranean climates: drought, low temperatures or both? Agric For Meteorol 206:151-162. https://doi. org/10.1016/j.agrformet.2015.03.004

San-Eufrasio B, Sánchez-Lucas R, López-Hidalgo C, Guerrero-Sánchez VM, Castillejo MA, Maldonado-Alconada AM, Jorrín-Novo JV, Rey MD (2020) Responses and differences in tolerance to water shortage under climatic dryness conditions in seedlings from Quercus spp. and Andalusian Q. ilex populations. Forests 11:707. https://doi.org/ 10.3390/f11060707

Scarascia-Mugnozza G, Oswald H, Piussi P, Radoglou K (2000) Forest of the Mediterranean region: gaps in knowledge and research needs. For Ecol Manag 132:97-109. https://doi.org/10.1016/S0378-1127(00)00383-2

Serrasolses I, Pérez-Devesa M, Vilagrosa A, Pausas JG, Sauras T, Cortina T, Vallejo RV (2009) Soil properties constraining Cork oak distribution. In: Aronson J, Pereira JS, Pausas JG (eds) Cork oak woodlands on the edge. Island Press, Washington DC, pp 89-101

Sevilla F (2008) Una teoría ecológica para los bosques ibéricos. Junta de Castilla y León, León

Silla F, Escudero A (2004) Nitrogen use efficiency: tradeoffs between $\mathrm{N}$ productivity and mean residence time at organ, plant and population level. Funct Ecol 18:511-521. https://doi.org/10.1111/j.0269-8463.2004.00872.x

Silla F, Escudero A (2006) Coupling N cycling and N productivity in relation to seasonal stress in Quercus pyrenaica Willd saplings. Plant Soil 282:301-311. https://doi.org/10. 1007/s11104-006-6249-1

Smit C, Díaz M, Jansen P (2009) Establishment limitation of holm oak (Quercus ilex subsp. ballota (Desf.) Samp.) in a Mediterranean savanna - forest ecosystem. Ann for Sci 66:511. https://doi.org/10.1051/forest/2009028

Stokes MA, Smiley TL (1968) An introduction to tree-ring dating. The University of Chicago Press, Chicago

Urbieta IR, Zavala MA, Marañon T (2008) Human and nonhuman determinants of forest composition in southern Spain: evidence of shifts towards cork oak dominance as a result of management over the past century. J Biogeogr 35:1688-1700. https://doi.org/10.1111/j.1365-2699.2008. 01914.X

Vallejo VR, Aronson J, Pausas JG, Pereira JS, Fontaine C (2009) The way forward. In: Aronson J, Pereira JS, Pausas JG (eds) Cork oak woodlands on the edge. Island Press, Washington DC, pp 235-245

Vessella F, López-Tirado J, Simeone MC, Schirone B, Hidalgo PJ (2017) A tree species range in the face of climate change: cork oak as a study case for the Mediterranean biome. Eur J Forest Res 136:555-569. https://doi.org/10. 1007/s10342-017-1055-2

Walkley A (1947) A critical examination of a rapid method for determining organic carbon in soils: effect of variations in digestion conditions and of inorganic soil constituents. Soil Sci 63:251-264

Wiegand T, Moloney KA (2014) Handbook of spatial pointpattern analysis in ecology. CRC Press, Boca Raton

Zang C, Biondi F (2013) Dendroclimatic calibration in $R$ : the bootRes package for response and correlation function 
analysis. Dendrochronologia 31:68-74. https://doi.org/10. 1016/j.dendro.2012.08.001

Zribi L, Mouillot F, Guibal F, Rejeb S, Rejeb MN, Gharbi F (2016) Deep soil conditions make Mediterranean cork oak stem growth vulnerable to autumnal rainfall decline in Tunisia. Forests 7:245. https://doi.org/10.3390/f7100245
Publisher's note Springer Nature remains neutral with regard to jurisdictional claims in published maps and institutional affiliations. 